\title{
Microbial flora associated with submerged mangrove leaf litter in India
}

\author{
Narayanasamy Rajendran \& Kandasamy Kathiresan \\ Centre of Advanced Study in Marine Biology, Annamalai University, Parangipettai - 608 502, Tamil Nadu, India; \\ cdl_aucasmb@sancharnet.in, kathirsum@rediffmail.com
}

Received 18-VIII-2003. C Corrected 28-VIII-2006. Accepted 15-XII-2006.

\begin{abstract}
We studied the microbial flora in decomposing mangrove leaves in relation to changes in nitrogen and tannin levels, and in penaeid prawn assemblages. Senescent leaves of two mangrove species (Rhizophora apiculata and Avicennia marina) kept in nylon bags, were separately immersed for 80 days in five tanks full of mangrove water. A known amount of decomposing leaves was collected every ten days from each tank for microorganism counts, total nitrogen and tannin measurement, and juvenile penaeid prawn counts. Five genera of total heterotrophic bacteria (THB), three species of azotobacters and 19 species of fungi were identified. The azotobacters showed a significant peak around 40-50 days after the beginning of of decomposition, similar to the trend for total nitrogen and for prawn assemblages. Rev. Biol. Trop. 55 (2): 393-400. Epub 2007 June, 29.
\end{abstract}

Key words: Rhizophora, Avicennia, litter, microbes, decomposition, Azotobacter.

Microorganisms play an important ecological role in decomposing organic matter and producing protein-rich detritus that serves as food to fishes especially in detritus-based marine ecosystems like mangroves (Dickinson and Pugh 1974, Steinke 2000, Mumby et al. 2004). Fungi are particularly important in the marine environment as decomposers of dead organic substrates (Kohlmeyer and Kohlmeyer 1979). The dead organic matter and the associated microorganisms form the base of the food webs of commercially important fishes and crustaceans. The undecomposed leaves are poor in nutrients, and they become nutritious due to the microbial enrichment process during decomposition (Odum 1971). The microbial decomposition of mangrove litter, has been extensively studied (Fell and Master 1973, 1980, Meyers 1974, Fell et al. 1975, 1980, Boonruang 1978, Cundell et al. 1979, Misra et al. 1984, Robertson 1988, Raghukumar et al. 1994, Rajendran and Kathiresan 1999a, 2000, Kathiresan and Bingham 2001, Rajendran and Kathiresan 2004) especially for the prevalence of fungi in decaying seedlings (Newell 1976). The microbial activity results in mineralization of detritus and a decrease in $\mathrm{C} / \mathrm{N}$ ratio (Blum et al. 1988).

Although microbes play an important role in the cycling of nutrients in the mangrove ecosystem, very little information is available about the types of microbes associated with decomposing leaves. These studies have not been extended to faunal assemblages associated with the decomposing leaves, especially for juvenile penaeid prawns which are usually abundant in mangrove waters (Rajendran 1997, Rajendran and Kathiresan 1999b, 2004). Hence, the present study was made on microbial load during decomposition of two mangrove species.

\section{MATERIALS AND METHODS}

Senescent leaves of Avicennia marina (Forsk.) Vierh., 1907 and Rhizophora apiculata Blume, 1827 were collected from a 
mangrove forest at Pichavaram $\left(11^{\circ} 27^{\prime} \mathrm{N}\right.$, $79^{\circ} 47^{\prime}$ E) located in southeast coast of India and shade-dried. The leaves weighing at 500 $\mathrm{g}$, without dissection, were packed in five nylon bags ( 35 x $35 \mathrm{~cm}, 2 \mathrm{~mm}$ mesh size) and submerged in five tanks $(1.5 \times 1.0 \mathrm{~m})$, which were constructed separately for Rhizophora and Avicennia in the lower intertidal areas adjacent to the mangrove forest. To facilitate the bags to sink, a stone weighing at $0.5 \mathrm{~kg}$ for each bag was added. The inner tank was covered with $2 \mathrm{~mm}$ (mesh size) nylon net to trap the juvenile prawns during decomposition of leaves. This experiment was continued for 80 days in the pre-monsoon months (JulySeptember 1999). During this period, the water temperature fluctuated between $27{ }^{\circ} \mathrm{C}$ and 32 ${ }^{\circ} \mathrm{C}$. The $\mathrm{pH}$ remained between 7.6 and 8 , the salinity varied between 24 and $31 \mathrm{gl}^{-1}$, and the dissolved oxygen ranged from 3.2 to $5.6 \mathrm{ml} \mathrm{l}^{-1}$. At every ten days of analysis, a known amount of decomposing leaves was collected randomly from each litter bags of both species for microbial and chemical analysis.

Level of total nitrogen in the decomposing leaves was analyzed using Technicon Autoanalyzer (Gradko Industrial Ltd., UK) and also level of tannins using the method described by Kathiresan and Veera Ravi (1990). During decomposition, prawn jóvenes were collected from the tank by lifting the inner net and were identified using the key characters given by Paulpandian and Ramasamy (1991).

For microbial analysis, the decomposing leaves were collected in clean and sterile polybags from litter bags and aseptically cut in to small pieces. These were then washed with sterilized seawater to remove debris on the leaves. Then they were dipped in $0.01 \%$ $\mathrm{HgCl}_{2}$ solution for $3 \mathrm{~min}$ for surface-sterilization of the pieces. The pieces were then washed with sterilized seawater to remove all the traces of $\mathrm{HgCl}_{2}$ solution. For estimating fungi, the pieces were then placed on plates with Martin rose bengal agar (Hi-Media Laboratories, Mumbai, India) medium incorporated with an antibiotic mixture (chlorotetracycline- $\mathrm{HCl}$
$10 \%$, chloramphenicol $2 \%$ and streptomycin sulphate $2 \%$; Van Uden and Fell 1968) for suppressing bacterial growth in the media.

For estimating total heterotrophic bacteria, ZoBell 2216E agar (Hi-Media Laboratories, Mumbai, India) medium was used; and for azotobacters, nitrogen-free mannitol agar medium was used (Buchanan and Gibbons 1974). Triplicate plates were incubated at room temperature $\left(28 \pm 2{ }^{\circ} \mathrm{C}\right)$ for $2-7$ days and the colonies were counted. The microbial counts are expressed as the number of colony forming units (CFU) per gram of wet leaf tissue. Bacteria including azotobacters were identified referring to Bergey's manual (Buchanan and Gibbons 1974) and fungi were identified following the keys given by Ainsworth et al. (1973) and Raper and Fennell (1987). The values were treated with two way analysis of variance (ANOVA) to find out the significance between the microbial load and other parameters. Correlation analysis between the variables was also analyzed (Snedecor 1956).

\section{RESULTS}

Total heterotrophic bacteria: In general, the total heterotrophic bacterial (THB) counts were more in decomposed leaves than in undecomposed ones. The counts reached a peak between 30 and 40 days of decomposition and declined thereafter. In Rhizophora apiculata, bacterial counts ranged from 1.60 x $10^{5}$ to $5.58 \times 10^{5}$ (no. g wet tissue ${ }^{-1}$ ) in the leaves decomposed for 10 and 30 days respectively as against $1.10 \times 10^{5}$ in undecomposed leaves. In Avicennia marina, the counts ranged from $1.78 \times 10^{5}$ to $8.56 \times 10^{5}$ in the leaves decomposed for 10 and 40 days respectively, as against $1.36 \times 10^{5}$ in the undecomposed leaves. However, there was no statistically significant variation in THB count between mangrove species $(\mathrm{ANOVA}=0.91, \mathrm{df}=1)$ and also among the days of decomposition $(\mathrm{ANOVA}=2.16, \mathrm{df}=8)$. The bacteria identified at generic levels were Flavobacterium, 
Vibrio, Pseudomonas, Acinetobacter and Corynebacterium.

Azotobacters: In general, count of azotobacters was more in decomposing leaves than in undecomposed ones (Fig. 1) and its peak existed between 30 and 50 days of decomposition and declined thereafter. This trend was similar in both species of mangroves. In $R$. apiculata, the counts ranged from $1.16 \times 10^{4}$ to $6.82 \times 10^{4}$ (no. $g$ wet tissue ${ }^{-1}$ ) in the leaves decomposed for 10 and 50 days respectively as against $1.33 \times 10^{4}$ in the undecomposed ones. In A. marina, the counts varied from $1.5 \times 10^{4}$ to $7.7 \times 10^{4}$ in the leaves decomposed for 10 and 40 days respectively, as against $2.6 \times 10^{4}$ in the undecomposed leaves. Of the two species of mangroves, the average count was more in $A$. marina $\left(4.11 \times 10^{4}\right)$ than in $R$. apiculata $(3.20$ $\mathrm{x} 10^{4}$ ). There was a statistically significant variation in counts of azotobacters between the days of decomposition $(\mathrm{ANOVA}=10.03$, $\mathrm{df}=8, \mathrm{p}<0.01)$, but not between the mangrove species $(\mathrm{ANOVA}=2.47, \mathrm{df}=1)$. Three species of azotobacters viz., A. chroococcum, A. vinelandii and $A$. beijerinckii were identified. The azotobacters exhibited a significant positive correlation $(r=0.785, p<0.05)$ with nitrogen in decomposing leaves.

Fungi: In general, the fungal counts attained a peak between 20 and 30 days of decomposition and declined thereafter. In $R$. apiculata, the counts were recorded maximum of 4464 (no. g wet tissue ${ }^{-1}$ ) in the 30 day decomposed leaves and minimum of 255

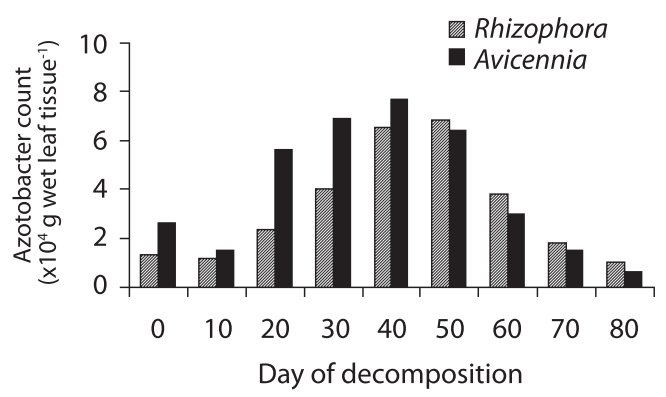

Fig. 1. Azotobacters in decomposing mangrove leaves. (no. g wet tissue ${ }^{-1}$ ) in the 80 day decomposed leaves, as against 500 (no. g wet tissue ${ }^{-1}$ ) in the undecomposed leaves. In A. marina, the fungal counts were recorded maximum of 1810 (no. $\mathrm{g}$ wet tissue ${ }^{-1}$ ) in the 20 day decomposed leaves and minimum of 142 (no. g wet tissue ${ }^{-1}$ ) in the 80 day decomposed leaves as against 700 (no. $\mathrm{g}$ wet tissue $\mathrm{e}^{-1}$ ) in the undecomposed leaves. However, there was no statistically significant variation in the fungal counts between the mangrove species $(\mathrm{ANOVA}=0.29, \mathrm{df}=1)$ and also among the days of decomposition (ANOVA= 2.02, $\mathrm{df}=8$ ).

The predominant fungal species identified from decomposing mangrove leaves were belonging to the genus Aspergillus. The species were Aspergillus niger, A. glaucus, A. fumigatus, $A$. candidus, $A$. verrucosa, $A$. smithii, A. flavus, A. ochraceus, A. aureolus and $A$. chevalier. Other species recorded were Alternaria alternata, Halosarphia fibrosa, Ophiobolus littoralis, Spathulospora lanata, Pontoporeia biturbinata, Fusarium sp., Mucor sp., Penicillium sp. and Curvularia sp.

Total Nitrogen: Total nitrogen was 0.11 $\%$ in $R$. apiculata and $0.17 \%$ in A.marina on the initial day of decomposition (Fig. 2). The level increased on the $30^{\text {th }}$ day onwards and showed maximum levels of $0.34 \%$ in the 50 day decomposed leaves of $R$. apiculata and $0.32 \%$ in the 40 day decomposed leaves of A. marina. There was a statistically significant variation in leaf nitrogen among the days of decomposition

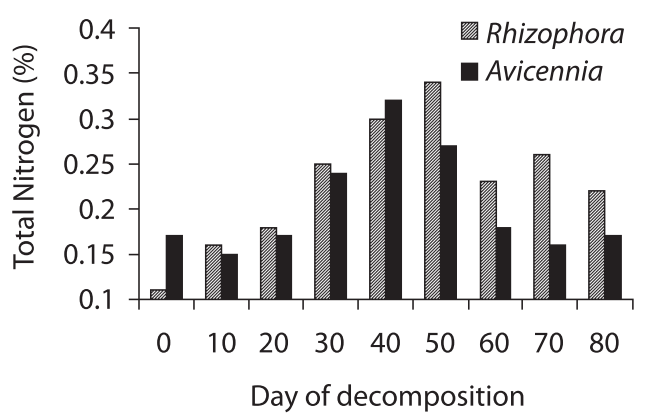

Fig. 2.Total nitrogen content in decomposing mangrove leaves. 
(ANOVA= 6.24, $\mathrm{df}=8, \mathrm{p}<0.01$ ), but not between the mangrove species $(\mathrm{ANOVA}=2.28, \mathrm{df}=1)$.

Tannin: The content of tannin in decomposing mangrove leaves is shown in Fig. 3 . The tannin content decreased during leaf decomposition, from $36.7 \mathrm{mg} \mathrm{g}^{-1}$ on the initial day to $1.9 \mathrm{mg} \mathrm{g}^{-1}$ on the 80 days of decomposition in $R$. apiculata and similarly from 18.3 $\mathrm{mg} \mathrm{g}^{-1}$ on initial day to $1.9 \mathrm{mg} \mathrm{g}^{-1}$ on 80 days of decomposition in A.marina. Thus there was $94.7 \%$ loss of tannin in R. apiculata and 89.6 $\%$ in A. marina within 80 days of decomposition. There was a significant difference in the content of tannin between the days of decomposition $(\mathrm{ANOVA}=5.93$, $\mathrm{df}=8, \mathrm{p}<0.05)$, and also between the mangrove species (ANOVA $=$ $5.75, \mathrm{df}=1, \mathrm{p}<0.05)$.

Juvenile prawns: The juvenile prawn's assemblage around decomposing mangrove leaves is depicted in Fig. 4. A higher number of juvenile prawns were found associated with decomposing A. marina leaves than $R$. apicula$t a$. The number was 5 tank $^{-1} \mathrm{day}^{-1}$ in the former and 2 tank $^{-1}$ day $^{-1}$ in the later in 40 days decomposed leaves. The values were statistically significant between species $(\mathrm{ANOVA}=5.22, \mathrm{df}=$ $1, \mathrm{p}<0.05)$ and among days of decomposition $(\mathrm{ANOVA}=6.06, \mathrm{df}=8, \mathrm{p}<0.01)$. The dominant prawn species identified were Penaeus indicus, Metapenaeus monoceros, M. dobsoni, M. brevicornis and Macrobrachium sp. The juvenile prawns exhibited a significant positive

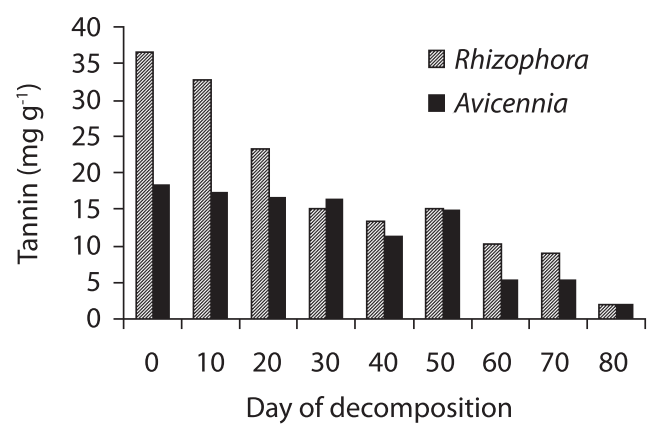

Fig. 3. Content of tannin in the decomposing mangrove leaves.

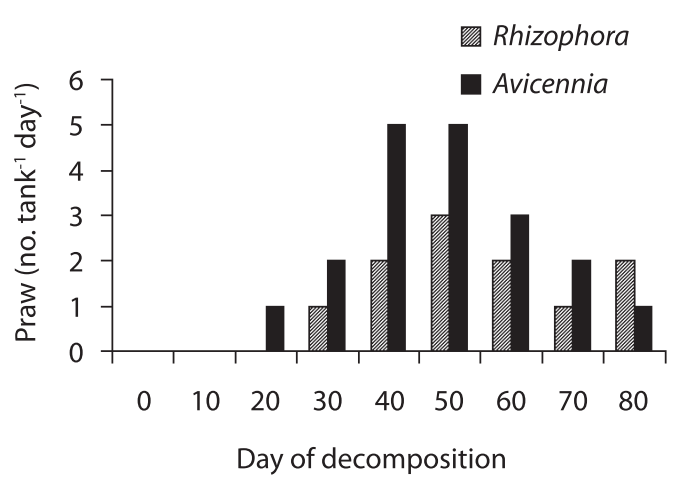

Fig. 4. Juvenile prawns associated with decomposing mangrove leaves.

correlation $(\mathrm{r}=0.909, \mathrm{p}<0.01)$ with nitrogen in decomposing leaves.

\section{DISCUSSION}

The microbial counts increased with days of decomposition of mangrove leaves. However, only the azotobacters showed a statistically significant increase during leaf decomposition. The azotobacters, isolated from the decomposed mangroves, were already proved in this laboratory to fix nitrogen (Ravikumar 1995). The nitrogen content, which was rich in decomposing leaves, as was found in the present study (Fig. 2), could be at least partially due to nitrogen-fixing bacteria like azotobacters (Fig. 1). Besides microbial biomass, it is now believed that increase in nitrogen content of marine detritus is due to the complexing of microbial exudates and enzymes with phenolics and carbohydrates to form recalcitrant, humic nitrogen (Melillo et al. 1984, Raghukumar et al. 1995).

The azotobacters which enrich nitrogen in the decomposing mangrove leaves may be a major factor in determining the palatability of detritus food to detritivorous animals like prawns. This supports our observation that there was an increasing trend in assemblage of juvenile prawns with days of leaf decomposition, with a peak around 40-50 days (Fig. 4), which was similar to the trend of total nitrogen content (Fig. 2) and azotobacter counts (Fig. 1). 
There was a highly significant positive correlation between

The count of azotobacters and nitrogen content of decomposing leaves $(r=0.785$, $\mathrm{p}<0.05$ ) and between nitrogen and juvenile prawns, associated with decomposing mangrove leaves $(\mathrm{r}=0.909, \mathrm{p}<0.01)$. Thus the azotobacters increase the level of nitrogen in decomposing mangrove leaves which perhaps attracts juvenile prawns.

The bacterial assemblage appears to depend on the content of tannin in the decomposing leaves. In the initial days of decomposition, the tannin content was high coinciding with low bacterial count. After the gradual leaching of tannin, the counts also increased. But the fungal count was high when content of tannin was high in the initial days of decomposition, after that the count declined with lowering of tannin (Rajendran 1997, Rajendran and Kathiresan 2000). This early colonization of fungi in tannin-rich mangrove leaves may be due to the fact that the fungi like Aspergilli are capable of producing tannase enzyme to degrade tannin (William et al. 1986). Tannin is known to inhibit the growth of fungi, but stimulate at low concentration (De et al. 1982). The bacterial diversity was high when phenol concentration was low in the mangrove sediment and the rate of biodegradation of leaves reduced at the high concentration of phenol (Joseph and Chandrika 1999, 2000).

In the present work, 19 species of fungi were isolated from the decomposing mangrove leaves with predominance of Aspergillus spp. Most of the species encountered in the present study were terrestrial forms, as was also observed by other workers (Rai et al. 1969, Venkatesan 1981, Miyoshi et al. 1985, Mohamed Salique 1989). The reason might be attributed to large scale transport of fungal spores from the land through freshwater inflow in to mangrove ecosystem. Several workers have already isolated mostly terrestrial species from the study area. Periasamy (1979) isolated 33 species of fungi from rhizosphere soil, pneumatophores and leaf litter of Avicennia officinalis. Venkatesan (1981) isolated 35 species of cellulolytic fungi from soil, root and litter of Avicennia officinalis and Rhizophora mucronata. Mohamed Salique (1989) recorded 23 species of fungi from the litter of $R$. apiculata and 19 species from Bruguiera cylindrica. The same author recorded 14 species of Aspergillus, with predominance of $A$. fumigatus and $A$. niger. Sivakumar and Kathiresan (1990) reported 10 species of fungi, found to occur on the surface of mangrove leaves, with dominance of Alternaria alternata and Rhizopus ingricam followed by Aspergillus and Penicillium species. Ravikumar and Kathiresan (1993) reported higher number of fungi on leaf litter than those on fresh leaves. Thirty one fungal isolates were recorded from soil and 27 species from decaying mangroves and seven species from floating plants were reported with dominance of Aspergillus followed by Penicillium, Fusarium and Trichoderma in Mangalvan mangrove ecosystem (Prabhakaran et al. 1987). Sixty seven fungal species were recorded from the intertidal wood samples with dominance of Lulworthia species and forty eight fungal species were identified from dead parts of Rhizophora mucronata prop roots (Poonyth et al. 1999). Sixty one species of higher marine fungi were collected from the submerged wood blocks of Bruguiera gymnorhiza and Rhizophora mucronata in Mauritius water (Poonyth et al. 2001). Seventy three species of fungi from Godavari and 67 species from Krishna estuaries of India were collected from the decaying samples of Rhizophora and Avicennia (Venkateswara Sarma et al. 2001). A total of 78 species of fungi belonging to 45 genera comprising 46 ascomycetes, one basidiomycetes and 31 deuteromycetes were recorded from the dead woods of mangroves in different parts of India (Maria and Sridhar 2002). One hundred and twenty five strains of endophytic fungi were isolated from the inner barks of three kinds of mangrove plants (Zheng 2003).

Both fungi and bacteria are important decomposers of mangrove leaves (Mohamed Salique 1989, Rajendran 1997). The role of fungi in decomposition of Rhizophora apiculata has also been proved under laboratory (Raghukumar et al. 1994). However, in the 
present study, there were no significant fungal and bacterial densities among the days of leaf decomposition, except for azotobacters. There might be significant variation in the microbial activities especially of enzymatic breakdown of decomposing leaves, which deserve more attention.

\section{ACKNOWLEDGMENTS}

The authors are grateful to the Director of the Centre of Advanced Study in Marine Biology and authorities of Annamalai University for providing facilities and to the Ministry of Environment and Forests, New Delhi, for financial support.

\section{RESUMEN}

Se estudió la flora microbiana en hojas en descomposición de mangles, considerando nitrógeno, taninos y camarones peneidos jóvenes. Colocamos hojas viejas de dos especies de mangle (Rhizophora apiculata y Avicennia marina) en bolsas de nylon y las sumergimos en agua de manglar durante 80 días usando cinco tanques separados. Cada diez días extrajimos una cantidad conocida de hojas en descomposición de cada tanque. Hallamos cinco géneros de bacterias heterotróficas totales (THB), tres especies de azotobacterias y 19 especies de hongos. Las azotobacterias presentaron un pico significativo de abundancia alrededor de los 40-50 días de descomposición, un patrón similar a los del nitrógeno total y los camarones.

Palabras clave: Rhizophora, Avicennia, hojarasca, microorganismos, descomposición, Azotobacter.

\section{REFERENCES}

Ainsworth, G.C., F.K. Sparrow \& A.S. Sussman. 1973. The Fungi an advanced Treatise. Academic, New York, USA. 621 p.

Blum, C.K., A.L. Mills, J.C. Ziemann \& R.T. Ziemann. 1988. Abundance of bacteria and fungi in seagrasses and mangrove detritus. Mar. Ecol. Prog. Ser. 42: $73-78$.

Boonruang, P. 1978. The degradation rates of mangrove leaves of Rhizophora apiculata (B1.) and Avicennia marina (Forsk.) Vierh. at Phuket Island Thailand. Phuket Mar. Biol. Cen. Res. Bull. 26: 1-7.

Buchanan, R.E. \& N.E. Gibbons. 1974. Bergey’s Manual of Determinative Bacteriology. The Williams \& Wilkins, Baltimore, Maryland, USA. 1246 p.

Cundell, A.M., M.S. Brown, R. Stanford \& R. Mitchell. 1979. Microbial degradation of Rhizophora mangle leaves immersed in the sea. Est. Coast. Mar. Sci. 9: 281-286.

De, V., V. Sheilla \& J. D’Souza. 1982. Studies on pectinolytic fungi from the mangrove sediments. Mahasagar 15: 167-173.

Dickinson, C.H. \& C.J.F. Pugh. 1974. Biology of plant litter decomposition. Academic, New York, USA. 775 p.

Fell, J.W. \& I.M. Master. 1973. Fungi associated with the decay of mangrove (Rhizophora mangle L.) leaves in South Florida, p. 455-456. In H.L. Stevenson \& R.R. Colwell (eds.). Estuarine Microbial Ecology. South Carolina, Columbia, USA.

Fell, J.W. \& I.M. Master. 1980. The association and potential role of fungi in mangrove detrital systems. Bot. Mar. 23: 257-263.

Fell, J.W., R.C. Cefalu, I.M. Master \& A.S. Tallman. 1975. Microbial activities in the mangrove (Rhizophora mangle) leaf detrital system, p. 661-679. In G. Walsh, S. Snedaker \& H. Teas (eds.). Proc. Intl. Symp. Biol. Manag. Mangroves. Hawaii, USA.

Fell, J.W., I.M. Master \& S.Y. Newell. 1980. Laboratory model of the potential role of fungi in the decomposition of red mangrove (Rhizophora mangle) leaf litter. p. 359-372. In K.R. Tenore \& B.C. Coull (eds.).Marine Benthic Dynamics. South Carolina, Columbia, USA.

Joseph, I. \& V. Chandrika. 1999. Biodegradation of phenol using bacteria from different brackishwater habitats. Indian J. Mar. Sci. 28: 438-442.

Joseph, I. \& V. Chandrika. 2000. Seasonal variations of sediment phenolics and aerobic heterotrophs in mangrove swamps. Indian J. Mar. Sci. 29: 52-56.

Kathiresan, K. \& A. Veera Ravi. 1990. Seasonal changes in tannin content of mangrove leaves. Indian For. 116: 390-392.

Kathiresan, K. \& B.L. Bingham. 2001. Biology of mangroves and mangrove ecosystems. Adv. Mar. Biol. 40: $81-251$. 
Kohlmeyer, J. \& E. Kohlmeyer. 1979. Marine mycology. Then higher fungi. Academic, New York, USA. 690 p.

Maria, G.L. \& K.R. Sridhar. 2002. Richness and diversity of filamentous fungi on woody litter of mangroves along the west coast of India. Curr. Sci. 83: 15731581.

Melillo, J.M., R.J. Naiman, J.D. Aber \& A.E. Linkins. 1984. Factors controlling mass loss and nitrogen dynamics of plant litter decaying in northern streams. Symp. Detritus Dynam. Aq. Ecosyst. 35: 341-356.

Meyers, S.P. 1974. Contribution of fungi to biodegradation of Spartina and other brackish marsh and vegetation. Veroff. Inst. Meeresforsch. Bremerh. Suppl. 5: 357-375.

Misra, S., Y. Vijaykumar, G. Amitabha \& J. Dutta. 1984. Microbial decomposition of Avicennia officinalis leaf litter in a mangrove forest biome: Biochemical changes during decomposition, p. 257-262. In V. Krishnamurthy \& A.G. Untawale (eds.). Marine Plants. Seaweed Research Utilization Association, Madras, India.

Miyoshi, H., R. Matuura \& Y. Hata. 1985. An ecological survey of fungi in the mangrove estuary of Shiira river, Iriomote Island, Okinawa. Rep. USA. Mar. Biol. Inst. Kochi University 7: 33-38.

Mohamed Salique, S. 1989. The production potential of the coastal ecosystems (with reference of fungi). Ph.D thesis, Annamalai, University, Parangipettai, India. $235 \mathrm{p}$.

Mumby, P.J., A.J. Edwards, J.E. Arias-González, K.C. Lindeman, P.G. Blackwell, A. Gall, M.I. Gorczynska, A.R. Harborne, C.L. Pescod, H. Renken, C.C. Wabnitz \& G. Llewellyn. 2004. Mangroves enhance the biomass of coral reef fish communities in the Caribbean. Nature 427: 533-536.

Newell, S.Y. 1976. Mangrove fungi: the succession in mycoflora of red mangrove (Rhizophora mangle L.) seedlings, p.51-91. In E.B.G. Jones (ed.). Recent advances in Aquatic Mycology. Elsevier, London, England.

Odum, E.P. 1971. Fundamentals of Ecology. WB Saunders, Philadelphia, USA. 574 p.

Paulpandian, A.L. \& A. Ramasamy. 1991. Guide to the prawns of Porto Novo (An identification manual) published by Centre of Advanced Study in Marine Biology. Annamalai, Parangipettai, India. 49 p.

Periasamy, R.1979. Mycoflora associated with Avicennia officinalis L. Master of Philosophy thesis, Madras University, Madras, India. 70 p.

Poonyth, A.D., K.D. Hyde \& A. Peerally. 1999. Intertidal fungi in Mauritian mangroves. Bot. Mar. 42: $243-$ 257.

Poonyth, A.D., K.D. Hyde \& A. Peerally. 2001. Colonization of Bruguiera gymnorrhiza and Rhizophora mucrona$t a$ wood by marine fungi. Bot. Mar. 44: 75-80.

Prabhakaran, N., R. Gupta \& M. Krishnankutty. 1987. Fungal activity in mangalvan: an estuarine mangrove ecosystem, p. 458-463. In B.N. Nair (ed.). Proc. Natl. Sem. Estuarine Management. Trivandrum, Kerala, India.

Raghukumar, S., S. Sharma, C. Raghukumar, V. Satha Pathak \& D. Chandramohan. 1994. Thraustochytrid and fungal component of marine detritus. 4. Laboratory studies on decomposition of leaves of the mangrove Rhizophora apiculata Blume. J. Exp. Mar. Biol. Ecol. 183: 113-131.

Raghukumar, S., V. Sathe Pathak, S. Sharma \& C. Raghukumar. 1995. Thraustochytrid and fungal component of marine detritus. 3. Field studies on decomposition of leaves of the mangrove Rhizophora apiculata. Aquat. Microb. Ecol. 9: 117-125.

Rai, J.N., J.P. Tewari \& K.G. Mukerji. 1969. Mycoflora of mangrove mud. Mycopathol. Mycol. Appl. 38: 17-33.

Rajendran, N. 1997. Studies on mangrove-associated prawn seed resources of the Pichavaram, south east coast of India. Ph.D. thesis, Annamalai University, Parangipettai, India. $135 \mathrm{p}$.

Rajendran, N. \& K. Kathiresan. 1999a. Do decomposing mangrove leaves attract fishes? Curr. Sci. 77: 972-976.

Rajendran, N. \& K. Kathiresan. 1999b. Seasonal occurrence of juvenile prawn and environmental factors in a Rhizophora mangal, southeast coast of India. Hydrobiologia 394: 193-200.

Rajendran, N. \& K. Kathiresan. 2000. Biochemical changes in decomposing mangrove leaves. Chem. Ecol. 17: $91-102$ 
Rajendran, N. \& K. Kathiresan. 2004. How to increase juvenile shrimps in mangrove waters? Wetl. Ecol. Mang. 12: 179-188.

Raper, K.B. \& D.I. Fennell. 1987. The genus Aspergillus. Robert E. Krieger, New York, USA. 686 p.

Ravikumar, S. 1995. Nitrogen-fixing azotobacters from the mangrove habitat and their utility as biofertilizer. Ph. D. thesis, Annamalai University, Parangipettai, India. $113 \mathrm{p}$.

Ravikumar, S. \& K. Kathiresan. 1993. Influence of tannins, sugars and amino acids on fungi of marine halophytes. Mahasagar 26: 21-24.

Robertson, A.I. 1988. Decomposition of mangrove leaf litter of tropical Australia. J. Exp. Mar. Biol. Ecol. 116: $235-247$.

Sivakumar, A. \& K. Kathiresan. 1990. Phylloplane fungi from mangroves. Indian J. Microbiol. 30: 229-231.

Snedecor, G.W. 1956. Statistical methods. The lowa state College, Ames, Iowa, USA. 534 p.
Steinke, T.D. 2000. Mangrove fungi on dead proproots of Rhizophora mucronata at three localities in South Africa. S. Afr. J. Bot. 66: 91-95.

Van Uden, N. \& J.W. Fell. 1968. Marine yeasts, p. 167201. In M. Droop \& E.J.F. Wood (eds.). Advances in Microbiology of the sea-I. Academic, London, England.

Venkatesan, T. 1981. Studies on mycoflora of Pichavaram mangroves near Porto Novo (South India). Ph.D. thesis, Annamalai University, Parangipettai, India. 236 p.

Venkateswara Sarma, V., K.D. Hyde \& B.P. Vittal. 2001. Frequency of occurrence of mangrove fungi from the east coast of India. Hydrobiologia 455: 41-53.

William, F., K. Boominathan, N. Vasudevan, G. Gurujeyalakshmi \& A. Mahadevan. 1986. Microbial degradation of lignin and tannin. J. Sci. Ind. Res. 45: 232-243.

Zheng, Z., M. Li, H. Yaojian, Xu. Qingyan \& Su. Wenjin. 2003. Antitumor activity of mangrove endophytic fungi. J. Xiamen Univ. Nat. Sci. 42: 511-516. 